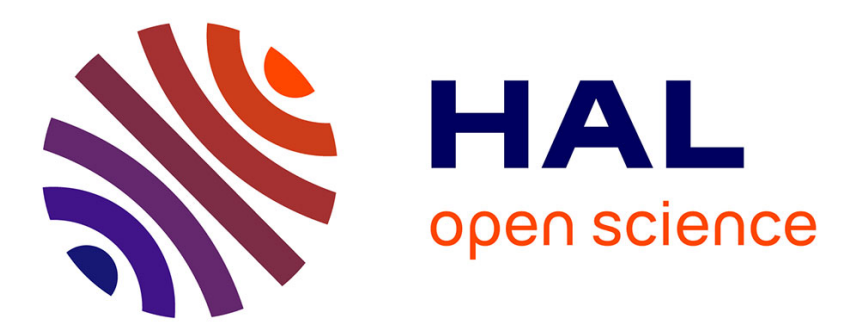

\title{
One-Step Synthesis of Calcium Hydroxyapatite from Calcium Carbonate and Orthophosphoric Acid under Moderate Conditions
}

\author{
Doan Pham Minh, Ngoc Dung Tran, Ange Nzihou, Patrick Sharrock
}

\section{- To cite this version:}

Doan Pham Minh, Ngoc Dung Tran, Ange Nzihou, Patrick Sharrock. One-Step Synthesis of Calcium Hydroxyapatite from Calcium Carbonate and Orthophosphoric Acid under Moderate Conditions. Industrial and engineering chemistry research, 2013, 52 (4), p. 1439-1447. 10.1021/ie302422d . hal-01632396

\section{HAL Id: hal-01632396 https://hal.science/hal-01632396}

Submitted on 20 Oct 2018

HAL is a multi-disciplinary open access archive for the deposit and dissemination of scientific research documents, whether they are published or not. The documents may come from teaching and research institutions in France or abroad, or from public or private research centers.
L'archive ouverte pluridisciplinaire HAL, est destinée au dépôt et à la diffusion de documents scientifiques de niveau recherche, publiés ou non, émanant des établissements d'enseignement et de recherche français ou étrangers, des laboratoires publics ou privés. 


\title{
One-Step Synthesis of Calcium Hydroxyapatite from Calcium Carbonate and Orthophosphoric Acid under Moderate Conditions
}

\author{
Doan Pham Minh, ${ }^{\dagger} *$ Ngoc Dung Tran, ${ }^{\dagger}$ Ange Nzihou, ${ }^{\dagger}$ and Patrick Sharrock ${ }^{\ddagger}$ \\ †Université de Toulouse, Mines Albi, CNRS, Centre RAPSODEE, Campus Jarlard, F-81013 Albi cedex 09, France \\ Université de Toulouse, SIMAD, IUT Paul Sabatier, Avenue Georges Pompidou, 81104 Castres, France
}

\begin{abstract}
Calcium hydroxyapatite ( $\mathrm{Ca}-\mathrm{HA})$ is a versatile material which can be used in several applications. This study aimed to investigate the one-step synthesis of $\mathrm{Ca}-\mathrm{HA}$ using solely calcium carbonate as-is and orthophosphoric acid as widely available and low cost initial reactants. The stirring rate and quantity of water had only some slight effects on the reaction rate. On the other hand, the reaction temperature influenced strongly the decomposition of the initial calcium carbonate particles and therefore the composition of the solids obtained. At $25-60{ }^{\circ} \mathrm{C}$, high contents of calcium carbonate remained in the solid products even after a long reaction time of $168 \mathrm{~h}$. At $80^{\circ} \mathrm{C}$, the decomposition of calcium carbonate was nearly complete after $24 \mathrm{~h}$ of reaction. Brushite $\left(\mathrm{CaHPO}_{4} \cdot 2 \mathrm{H}_{2} \mathrm{O}\right)$ and octacalcium phosphate $\left(\mathrm{OCP}, \mathrm{Ca}_{8}\left(\mathrm{HPO}_{4}\right)_{2}\left(\mathrm{PO}_{4}\right)_{4} \cdot 5 \mathrm{H}_{2} \mathrm{O}\right)$ were the main intermediates of the reaction. When the decomposition of calcium carbonate was complete $\left(80^{\circ} \mathrm{C}, 24 \mathrm{~h}\right)$, stoichiometric $\mathrm{Ca}-\mathrm{HA}$ was obtained, with some little amounts of carbonate-containing apatites of both A-type and B-type. Carbon dioxide was the only by-product of the reaction, and no water rinsing was required for the purification of products.
\end{abstract}

\section{INTRODUCTION}

Calcium hydroxyapatite $\left(\mathrm{Ca}-\mathrm{HA}, \mathrm{Ca}_{10}\left(\mathrm{PO}_{4}\right)_{6}(\mathrm{OH})_{2}\right)$ continues to attract much attention because of its numerous applications in the fields of biomaterial, ${ }^{1-3}$ heterogeneous catalysis, ${ }^{4-7}$ gas sensors, ${ }^{8,9}$ and wastewater treatment, etc. ${ }^{10,11}$ Thus, much work has been done on the synthesis of $\mathrm{Ca}-\mathrm{HA}$ using different methods such as solid-solid reaction, ${ }^{12,13}$ ultrasonic spray freeze-drying, ${ }^{14}$ or spray-drying techniques generating $\mathrm{Ca}-\mathrm{HA}$ powder of controlled morphology, ${ }^{15}$ sol-gel technique, ${ }^{16-18}$ precipitation in aqueous solution, ${ }^{19-22}$ emulsion route, ${ }^{23,24}$ microwaveassisted synthesis, ${ }^{25}$ synthesis under hydrothermal conditions, ${ }^{26,27}$ or synthesis using templates, etc. ${ }^{28,29}$ The precipitation of orthophosphate species by a calcium source in an aqueous solution seems to be the most general technique to prepare $\mathrm{Ca}-\mathrm{HA}$ powder particles. By this route, water-soluble calcium sources such as calcium nitrate, calcium chloride, or calcium acetate are preferred because of the resulting homogeneity of the reaction medium. Consequently, stoichiometric $\mathrm{Ca}-\mathrm{HA}$ of high purity can be obtained for high value-added materials, for example in medicine $^{30}$ or chromatography column making. ${ }^{31,32}$ Nevertheless, these soluble calcium salts present some drawbacks concerning their relative high costs in comparison with less watersoluble calcium sources, such as calcium hydroxide or calcium carbonate; the arduous washing steps when nanoparticles of $\mathrm{Ca}-$ $\mathrm{HA}$ are formed; and the treatment of waste by-product from counterions. In addition, when $\mathrm{Ca}-\mathrm{HA}$ materials are used as sorbents in environmental applications, they must be of low-cost. Thus, calcium carbonate would appear as the most interesting starting material for the calcium source.

In our previous work, a comparative study on the synthesis of $\mathrm{Ca}-\mathrm{HA}$ from calcium carbonate and different orthophosphate sources was demonstrated. ${ }^{33}$ Orthophosphoric acid was found to represent the best orthophosphate source because of a high dissolution of calcium carbonate and a complete precipitation of the orthophosphate species. However, the initial calcium carbonate could not be completely decomposed at room temperature, despite a long reaction time of $48 \mathrm{~h} .{ }^{33}$

This work aims to find the proper conditions to synthesize $\mathrm{Ca}-\mathrm{HA}$ starting from calcium carbonate and orthophosphoric acid under moderate conditions, which are comparable to those of the competing industrial process using calcium hydroxide and orthophosphoric acid. Different parameters of the reaction were investigated in order to define a one-step synthesis process of $\mathrm{Ca}-\mathrm{HA}$ with complete conversion of calcium carbonate. The usual parameters examined for promotion of biphasic reaction are stirring speed, liquid to solid ratio $(\mathrm{L} / \mathrm{S})$, reaction time, and reaction temperature. All these are expected to influence reaction outcomes.

\section{MATERIALS AND METHODS}

Calcium carbonate powder (98\%, Fisher Scientific) and orthophosphoric acid ( $85 \mathrm{wt} \%$ in water, Merck) were used as received. The preparation of $\mathrm{Ca}-\mathrm{HA}$ was carried out in a $2.3 \mathrm{~L}$ glass U-form reactor (i.d., $10 \mathrm{~cm}$; length, $30 \mathrm{~cm}$ ) equipped with a vertical stainless steel two-blade mixing rotor. For each synthesis, $100 \mathrm{~g}$ of calcium carbonate powder and $260-530 \mathrm{~g}$ of permuted water, which corresponded to different weight ratios of water to calcium carbonate $(\mathrm{L} / \mathrm{S})$, were introduced in the reactor under stirring (200-600 rpm). Then $69.2 \mathrm{~g}$ of orthophosphoric acid were pumped into the reactor at the rate of $1 \mathrm{~mL} \mathrm{~min}^{-1}$. This corresponded to a molar ratio of calcium to phosphorus $(\mathrm{Ca} / \mathrm{P})$ of 1.67 which is the stoichiometric $\mathrm{Ca} / \mathrm{P}$ of $\mathrm{Ca}-\mathrm{HA}$. During the reaction, the reaction temperature was kept constant at $25-80^{\circ} \mathrm{C}$. Powder products were obtained by filtration of the suspension on 
a $0.45 \mu \mathrm{m}$ filter paper followed by a drying overnight at $105^{\circ} \mathrm{C}$. Table 1 summarizes the synthesis conditions used.

Table 1. Reaction Conditions Used in the Synthesis of $\mathrm{Ca}-\mathrm{HA}$

\begin{tabular}{ccccc} 
synthesis & $\begin{array}{c}\text { L/S } \\
\text { ratio }\end{array}$ & $\begin{array}{c}\text { stirring } \\
(\mathrm{rpm})\end{array}$ & $\begin{array}{c}\text { reaction temperature } \\
\left({ }^{\circ} \mathrm{C}\right)\end{array}$ & reaction time $(\mathrm{h})$ \\
Syn-1 & 4.5 & 200 & 25 & 24 \\
Syn-2 & 4.5 & 400 & 25 & 24 \\
Syn-3 & 4.5 & 600 & 25 & 24 \\
Syn-4 & 2.6 & 400 & 25 & 24 \\
Syn-5 & 3.9 & 400 & 25 & 24 \\
Syn-6 & 5.3 & 400 & 25 & 24 \\
Syn-7 & 4.5 & 600 & 25 & $3-24-96-168$ \\
Syn-8 & 4.5 & 600 & 60 & $3-24-96-168$ \\
Syn-9 & 4.5 & 600 & 80 & $3-24$ \\
& & & & \\
\hline
\end{tabular}

Elemental analysis was carried out using inductively coupled plasma atomic emission spectroscopy (ICP-AES) on a HORIBA Jobin Yvon Ultima 2. Thermogravimetry analysis (TGA) was carried out with a TA Instruments SDTQ600 analyzer (air flow rate at $100 \mathrm{~mL} \mathrm{~min}^{-1}$; heating rate of $20^{\circ} \mathrm{C} \mathrm{min}^{-1}$ ). Exhaust gases from the outlet of TG analyzer were analyzed by Pfeiffer Vacuum OmniStar GSD 320 mass spectrometer which acquires mass spectra from 0 to $60 \mathrm{amu}$ (atomic mass unit). Infrared spectroscopy (IR) was performed on a Shimadzu FTIR 8400 s spectrometer in the wavenumber range 4000-500 $\mathrm{cm}^{-1}$. X-ray diffraction (XRD) measurements were carried out using a Phillips Panalytical X'pert Pro MPD diffractometer with a $\mathrm{Cu} \mathrm{K} \alpha(1.543 \AA)$ radiation source. Specific surface area was determined on a Micrometrics Gemini Vacprep 061 apparatus using the BET method $\left(S_{\mathrm{BET}}\right)$ by nitrogen adsorption. Scanning electron microscopy (SEM) measurement was performed on a Philips XL30 ESEM apparatus (FEI Company). Particle size distribution was measured by laser scattering in a Mastersizer 2000 (Malvern Instruments Ltd., Malvern, UK) in the range from 0.020 to $2000 \mu \mathrm{m}$. The median diameters $\left(d_{50}\right)$ were obtained from particle number size distributions.

\section{RESULTS}

3.1. Determination of the Contents of Brushite and Remaining Calcium Carbonate. To evaluate the advancement of the reaction, TG analysis was performed in order to determine the contents of remaining calcium carbonate, which was the starting reactant, and brushite $\left(\mathrm{CaHPO}_{4} \cdot 2 \mathrm{H}_{2} \mathrm{O}\right)$, which was a principal intermediate of the reaction. ${ }^{33}$ As an example, Figure 1 illustrates TG (A) and DTG (B) curves of the solid product obtained after $3 \mathrm{~h}$ of reaction at $25^{\circ} \mathrm{C}, 600 \mathrm{rpm}$ and $\mathrm{L} / \mathrm{S}$ ratio of 4.5 (Syn-7, Table 1).

Under the analysis conditions used, the remaining calcium carbonate decomposed in the temperature range of $600-710^{\circ} \mathrm{C}$ with the $\mathrm{DTG}_{\max }$ (the maximum of the DTG signal) of $688^{\circ} \mathrm{C}$ (eq 1). This led to a weight loss by the release of $\mathrm{CO}_{2}$ in gas phase. From this weight loss, the content of remaining calcium carbonate could easily be calculated, according to eq 1 . As for brushite, its dehydration took place between 170 and $199{ }^{\circ} \mathrm{C}$, with the $\mathrm{DTG}_{\max }$ of $186{ }^{\circ} \mathrm{C}$. The content of brushite was calculated according to eq 2 .

$$
\begin{aligned}
& \mathrm{CaCO}_{3} \rightarrow \mathrm{CaO}+\mathrm{CO}_{2} \\
& \mathrm{CaHPO}_{4} \cdot 2 \mathrm{H}_{2} \mathrm{O} \rightarrow \mathrm{CaHPO}_{4}+2 \mathrm{H}_{2} \mathrm{O}
\end{aligned}
$$

To confirm the results mentioned above, qualitative analysis of gas from the outlet of TG analyzer was also performed using the MS technique. Figure 2 shows the evolutions of $\mathrm{H}_{2} \mathrm{O}(18 \mathrm{amu})$

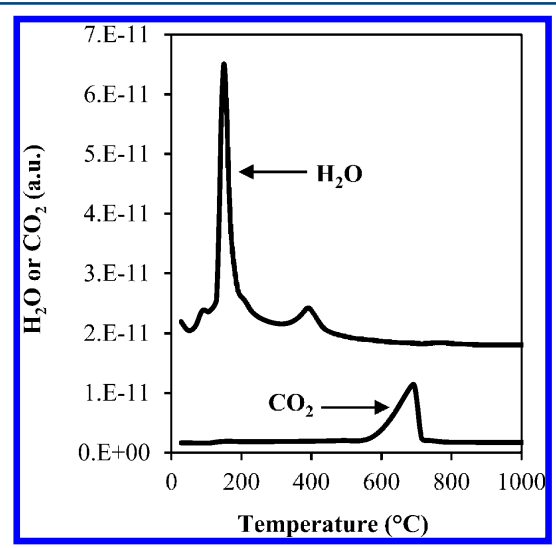

Figure 2. Example of qualitative analysis of $\mathrm{H}_{2} \mathrm{O}$ and $\mathrm{CO}_{2}$ formed during TG analysis using the MS technique.

and $\mathrm{CO}_{2}(44 \mathrm{amu})$ as a function of temperature corresponding to TG analysis in Figure 1 . The weight losses in the temperature ranges of $170-199^{\circ} \mathrm{C}$ and $600-710^{\circ} \mathrm{C}$ evidently corresponded to the dehydration of brushite and the decarbonation of remaining

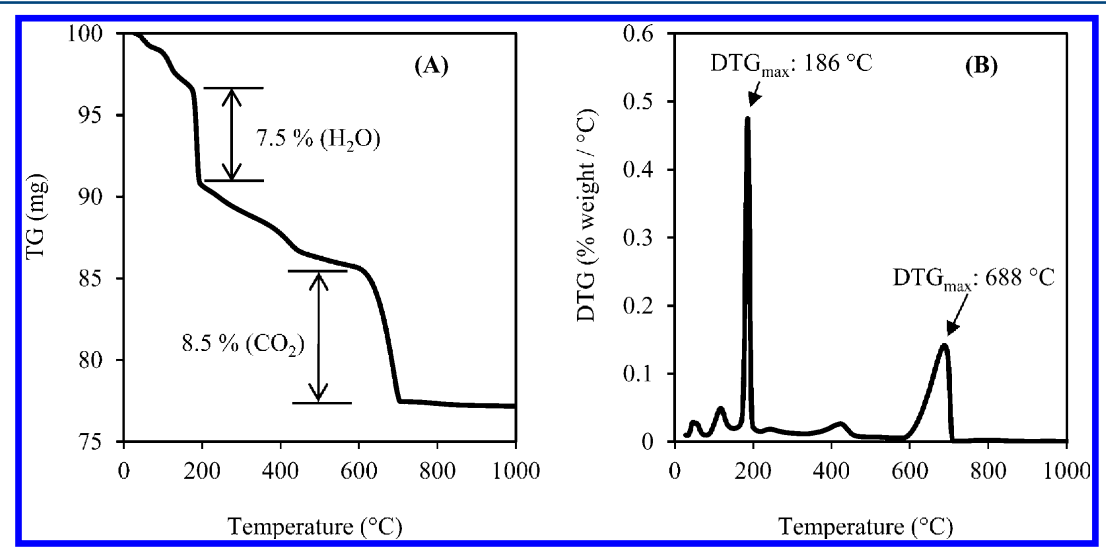

Figure 1. Example of TG (A) and DTG (B) curves and the determination of $\mathrm{DTG}_{\max }$ and the contents of brushite and remaining calcium carbonate. 


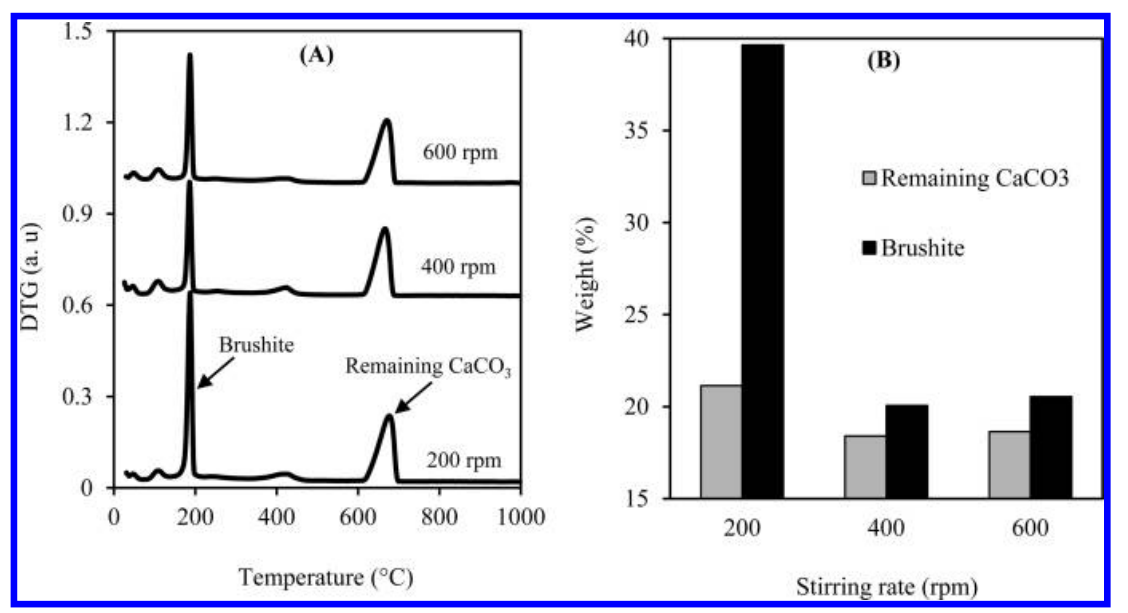

Figure 3. DTG curves (A) and contents of brushite and remaining calcium carbonate (B) of the filtered solid products at different stirring rates. Synthesis conditions: reaction temperature of $25{ }^{\circ} \mathrm{C}, \mathrm{L} / \mathrm{S}$ ratio of 4.5 , reaction time of $24 \mathrm{~h}$ (Syn-1, Syn-2, and Syn-3 in Table 1).

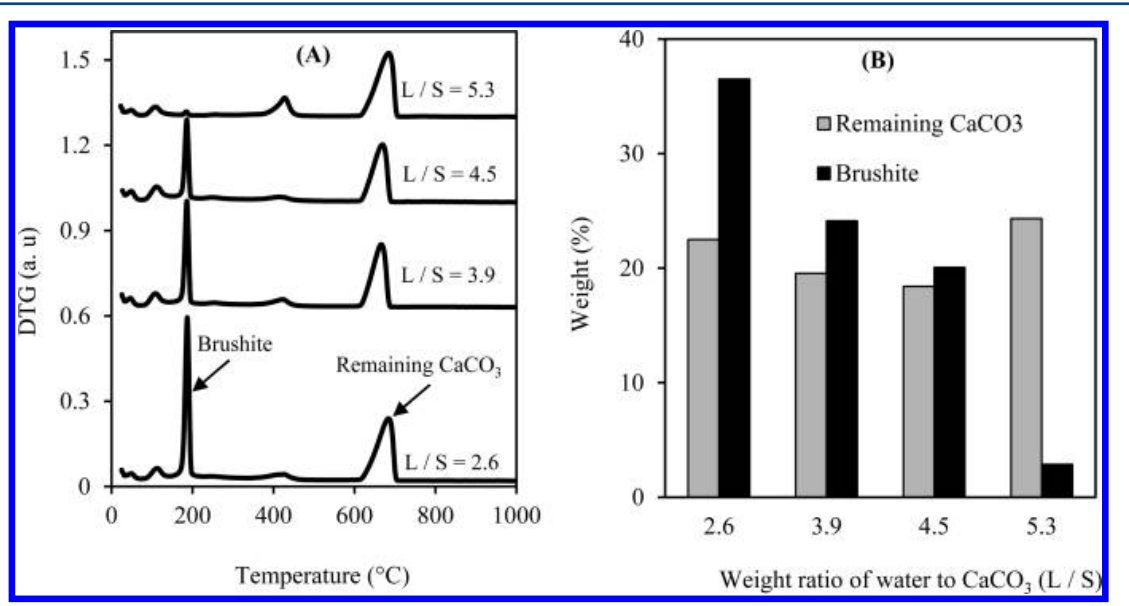

Figure 4. DTG curves (A) and contents of brushite and remaining calcium carbonate (B) of the filtered solid products at different weight ratios of water to calcium carbonate $(\mathrm{L} / \mathrm{S})$. Synthesis conditions: reaction temperature of $25^{\circ} \mathrm{C}$, stirring rate of $400 \mathrm{rpm}$, reaction time of $24 \mathrm{~h}$ (Syn-2, Syn- 4 , Syn-5, and Syn-6 in Table 1).

calcium carbonate, respectively. These results were consistently found for all TG analyses presented in the next sections.

3.2. Effect of Stirring Rate. To improve the decomposition of calcium carbonate, the influence of different parameters such as the stirring rate, the weight ratio of water to calcium carbonate, the reaction temperature, and the reaction time, were investigated.

Figure 3A presents the DTG curves and Figure 3B compares the contents of brushite and the remaining calcium carbonate of the solid products obtained at different stirring rates. Different weight losses were observed in the temperature range of 25$1000{ }^{\circ} \mathrm{C}$, which were already discussed in our previous work. ${ }^{33}$ By increasing the stirring rate from 200 to $400 \mathrm{rpm}$, the content of remaining calcium carbonate decreased from 21.1 to $18.4 \%$. A strong decrease of the content of brushite from 39.6 to $20.1 \%$ was also observed. The increase of the stirring rate favored the contact of calcium carbonate particles with orthophosphate species, and therefore favored its decomposition. However, the increase of the stirring rate to $600 \mathrm{rpm}$ did not lead to any further significant improvement, indicating that other parameters need to be optimized.

3.3. Effect of L/S ratio. The amount of water used as solvent of the reaction could also influence the advancement of the reaction. Thus, the effect of the $\mathrm{L} / \mathrm{S}$ ratio was investigated in the range of 2.6-5.3 and the results are presented in Figure 4.

Under similar reaction conditions, the best $\mathrm{L} / \mathrm{S}$ ratio was found to be 4.5 , leading to the lowest content of remaining calcium carbonate, which was $18.4 \%$. A lower L/S ratio might lead to a heterogeneity of the reaction mixture and reduced contact of the calcium carbonate particles with the orthophosphate species. A higher L/S ratio increased the homogeneity of the reaction mixture, but decreased the reaction rate because of the dilution of the initial reactants. As for brushite, its content decreased continuously with the increase of the L/S ratio. The increase of the L/S ratio induced a better solubility of brushite, formed during the reaction as a first intermediate, and therefore favored its transformation into other intermediates such as dicalcium phosphate anhydrous (DCPA, $\mathrm{CaHPO}_{4}$ ) or octacalcium phosphate (OCP, $\left.\mathrm{Ca}_{8}\left(\mathrm{HPO}_{4}\right)_{2}\left(\mathrm{PO}_{4}\right)_{4} \cdot 5 \mathrm{H}_{2} \mathrm{O}\right)$.

3.4. Effect of Reaction Time and Reaction Temperature. In the ranges of stirring rate and $\mathrm{L} / \mathrm{S}$ ratio investigated, the content of remaining calcium carbonate was still appreciable. Thus, the influence of the reaction time and reaction temperature were studied. Figure 5 presents the results of TG analysis of the solid products synthesized at $25{ }^{\circ} \mathrm{C}$ for different reaction times. The contents of both brushite and remaining calcium carbonate 


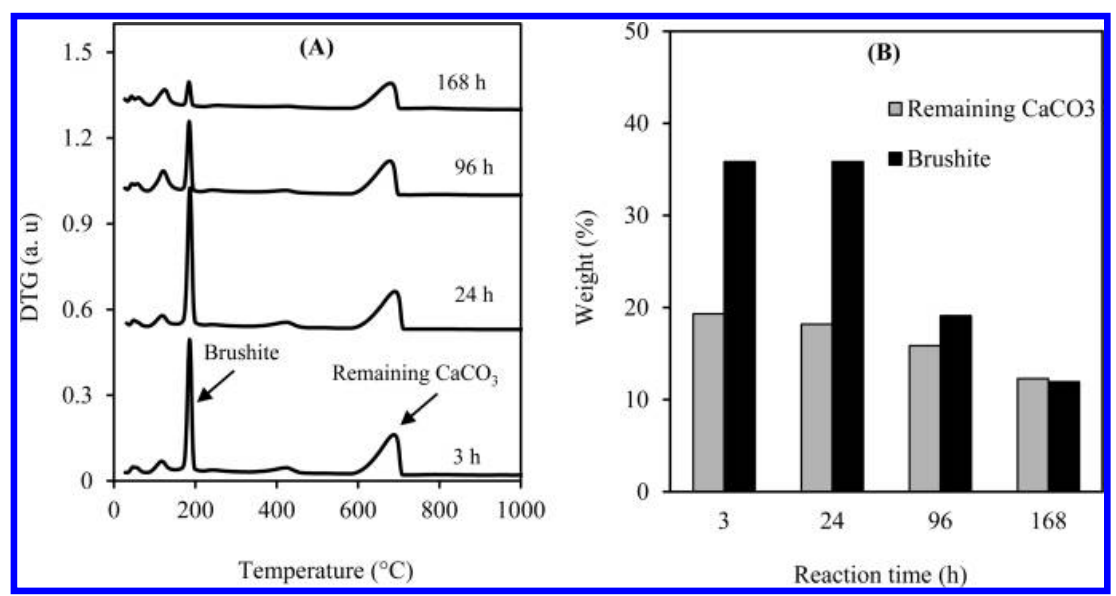

Figure 5. DTG curves (A) and contents of brushite and remaining calcium carbonate (B) of the filtered solid products at different reaction times. Synthesis conditions: reaction temperature of $25^{\circ} \mathrm{C}$, stirring rate of $600 \mathrm{rpm}, \mathrm{L} / \mathrm{S}$ ratio of 4.5 (Syn-7 in Table 1 ).

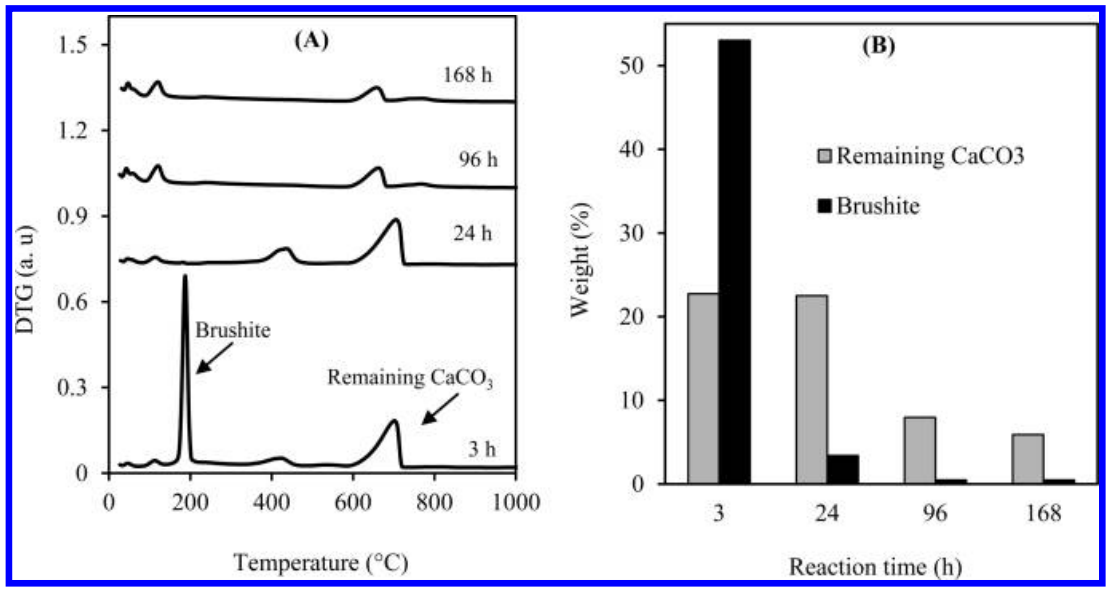

Figure 6. DTG curves (A) and contents of brushite and remaining calcium carbonate (B) of the filtered solid products at different reaction times. Synthesis conditions: reaction temperature of $60^{\circ} \mathrm{C}$, stirring rate of $600 \mathrm{rpm}, \mathrm{L} / \mathrm{S}$ ratio of 4.5 (Syn-8 in Table 1).

decreased with the reaction time, but with slow rates. After $168 \mathrm{~h}$ (or 7 days), the content of remaining calcium carbonate was still $12.3 \%$. The reaction mixture had and maintained the appearance of a gel throughout this long reaction time.

To accelerate the reaction, a higher reaction temperature was required. Figure 6 shows the results of TG analysis of the solid products synthesized at $60{ }^{\circ} \mathrm{C}$. Brushite appeared also at high content at the beginning of the reaction, and then its content decreased rapidly. Only trace amounts of brushite were found after $96-168 \mathrm{~h}$ of reaction, indicating the influence of reaction temperature on the advancement of the reaction, in comparison with the results in Figure 5. The content of remaining calcium carbonate also decreased with the reaction time, but was still $5.9 \%$ after $168 \mathrm{~h}$ of reaction. Therefore, another synthesis was carried out at $80^{\circ} \mathrm{C}$, and the results of TG analysis are presented in Figure 7.

Figure 7 illustrates the crucial effect of the reaction temperature on the advancement of the reaction. At $80^{\circ} \mathrm{C}$, the decomposition of calcium carbonate reached nearly completion after only $24 \mathrm{~h}(>99.5 \%)$. The amount of brushite was also very small. ICP-AES analysis of the liquid phase after $24 \mathrm{~h}$ of reaction showed only trace amounts of soluble calcium cations and orthophosphates species. Thus, the transformation of both initial reactants (calcium carbonate and orthophosphoric acid) into solid calcium phosphates was complete. The TG analyses confirmed the hypothesis and provided simple and sensitive results. However, the identification of these calcium phosphates needs other physico-chemical characterizations.

3.5. Physico-chemical Characterizations of the Solid Products. TG analyses allowed the quantification of the remaining calcium carbonate present in the solid products, and therefore the advancement of the reaction could be evaluated. It is interesting to analyze in more details the most significant solid products using other physico-chemical characterizations. The following products were selected for further studies: solids obtained at $25^{\circ} \mathrm{C} / 168 \mathrm{~h} ; 60^{\circ} \mathrm{C} / 168 \mathrm{~h} ; 80^{\circ} \mathrm{C} / 3 \mathrm{~h}$, and $80^{\circ} \mathrm{C} / 24 \mathrm{~h}$; which are labeled thereafter P25-168; P60-168; P80-003; P80-024, respectively.

3.5.1. XRD. XRD characterization was carried out in order to investigate crystalline phases of the selected solid products. The results are presented in Figure 8 wherein most principal diffraction peaks are designated. The remaining calcium carbonate, having the main diffraction peak at 2 theta of $29.40 \mathrm{deg}$, was clearly observed for the P25-168 and P60-168 samples. This peak was much less intense for P80-003 solid and was nearly negligible for P80-024 solid. Brushite with the main diffraction peak at 2 theta of $23.40 \mathrm{deg}$ appeared only in P25-168 sample. These results confirmed again those of TG analysis (Figures 5, 6, 7).

The second crystalline calcium phosphate detected by XRD was OCP. Its content was highest in the P25-168 sample, where 


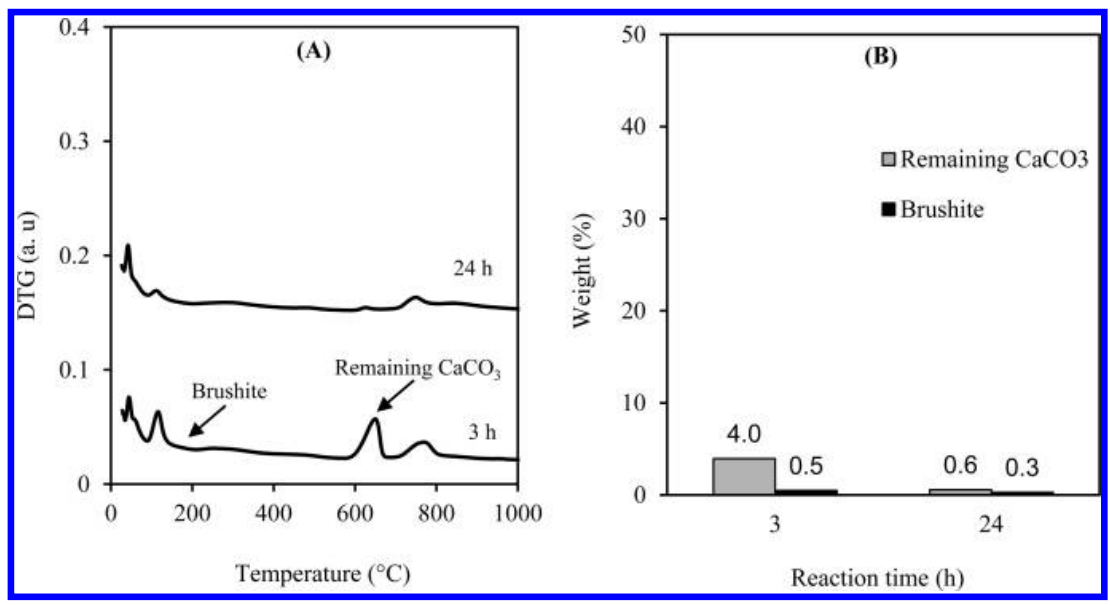

Figure 7. DTG curves (A) and contents of brushite and remaining calcium carbonate (B) of the filtered solid products at different reaction times. Synthesis conditions: reaction temperature of $80^{\circ} \mathrm{C}$, stirring rate of $600 \mathrm{rpm}, \mathrm{L} / \mathrm{S}$ ratio of 4.5 (Syn-9 in Table 1).

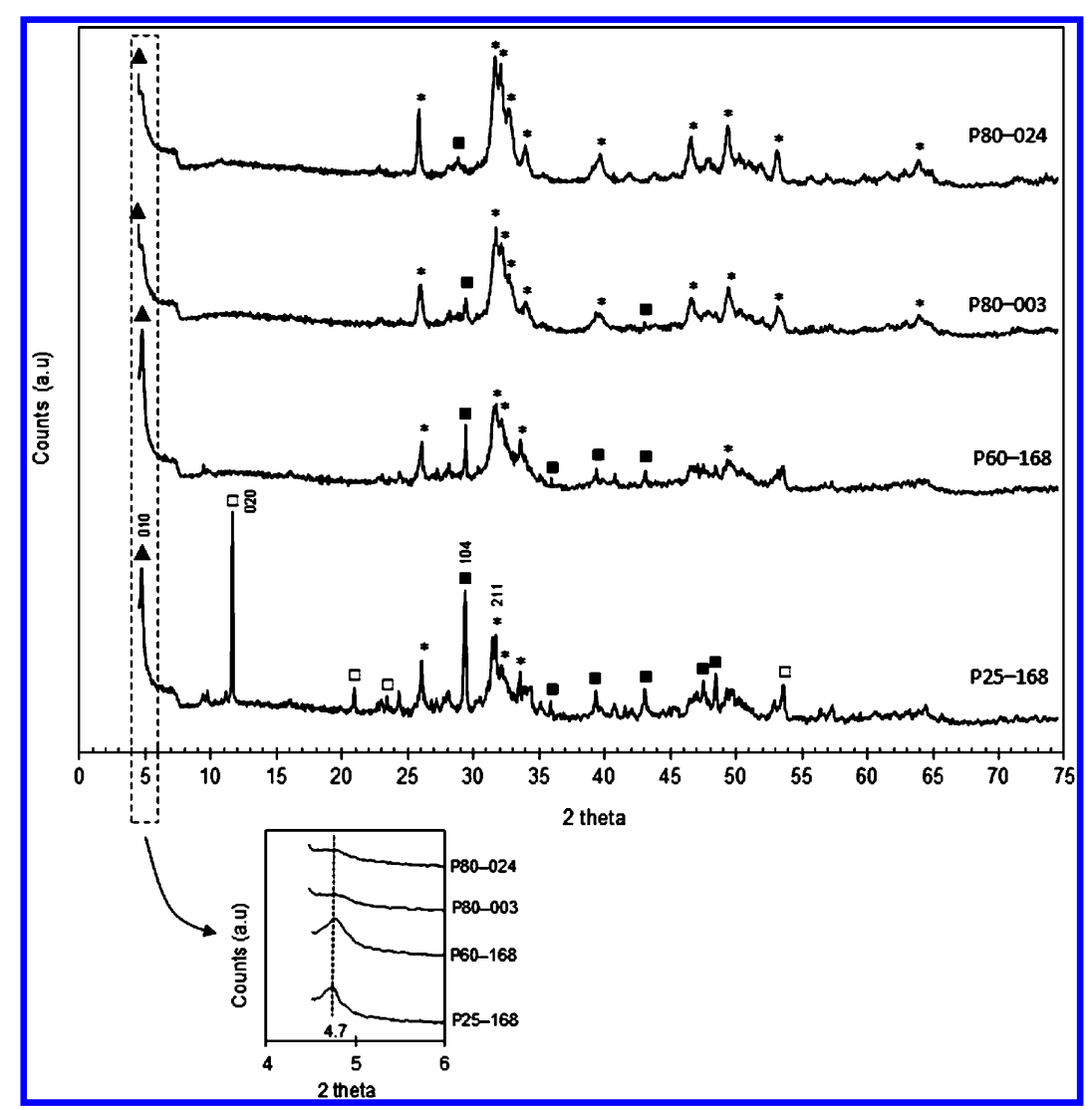

Figure 8. XRD patterns of the selected solid products: (A) OCP (JCPDS standard No. 00-026-1056); (*) Ca-HA (JCPDS standard No. 01-072-

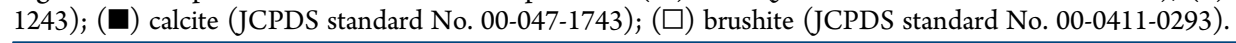

the content of remaining calcium carbonate was highest. As a function of the decomposition of the initial calcium carbonate, the content of OCP considerably decreased and was only in trace amounts in the P80-003 and P80-024 samples, taking into account the instability of the XRD background for the 2 theta lower than 7 degrees. ${ }^{34}$ For the synthesis at $80{ }^{\circ} \mathrm{C}$, the reaction was stopped at $24 \mathrm{~h}$ because the decomposition of calcite was already quite complete. Stoichiometric $\mathrm{Ca}-\mathrm{HA}$ appeared in all four solid products as stable calcium phosphate. Its content increased with the decomposition of the initial calcium carbonate and the disappearance of OCP. In all our syntheses, weak broad peaks of $\mathrm{Ca}-\mathrm{HA}$ were observed, which were characteristic for the formation of poorly crystallized $\mathrm{Ca}-\mathrm{HA}$ by precipitation in aqueous solution. ${ }^{21,33,35}$ Carbonate-containing apatites (CAP) might also be present, but at low contents, as confirmed by IR results in the next section.

3.5.2. Infrared. IR spectra of the selected solid products and the initial calcium carbonate are shown in Figure 9. For the initial calcium carbonate, three net peaks at $711 \mathrm{~cm}^{-1}, 872 \mathrm{~cm}^{-1}$, and $1389 \mathrm{~cm}^{-1}$ were observed in the wavenumbers from 1700 to 


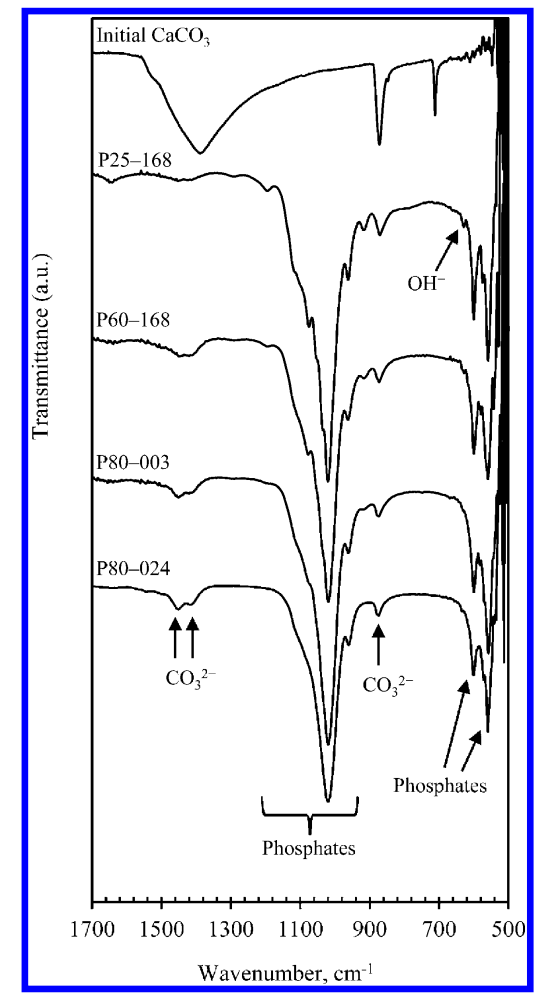

Figure 9. IR spectra of the selected solid products and initial calcium carbonate.

$500 \mathrm{~cm}^{-1}$, which are the characteristic peaks of calcite. ${ }^{36}$ For the synthesized solids, there was only a weak broad peak at $3570 \mathrm{~cm}^{-1}$ in the wavenumber range of $4000-1700 \mathrm{~cm}^{-1}$, which was attributed to hydroxyl groups (not presented).

In the wavenumber of $1700-500 \mathrm{~cm}^{-1}$, a weak peak at $1389 \mathrm{~cm}^{-1}$ was observed for the sample P25-168, despite its high content of remaining calcium carbonate (12.3\%). In fact, previous work revealed that the remaining calcium carbonate particles were usually covered by calcium phosphate layers ${ }^{37}$ and therefore it was only partially detected by IR. This peak nearly disappeared in three other selected solid products, due to the decrease of the content of remaining calcium carbonate. On the other hand, peaks of carbonate groups incorporated in the structure of $\mathrm{Ca}-\mathrm{HA}$ were observed, and their intensity increased with the reaction temperature, or the decomposition of calcium carbonate (Figure 10). The replacement of both $\mathrm{OH}^{-}$groups (A-type CAP, characterized by the bimodal peak at $1450 \mathrm{~cm}^{-1}$ / $1415 \mathrm{~cm}^{-1}$ and the peak at $873 \mathrm{~cm}^{-1}$ ) and $\mathrm{PO}_{4}{ }^{3-}$ groups (B-type CAP, characterized by the peaks at 1545 and $\left.880 \mathrm{~cm}^{-1}\right)^{38,39}$ was observed for both products synthesized at $80{ }^{\circ} \mathrm{C}$ (P80-003 and P80-024). On the other hand, the products synthesized at 25 and $60{ }^{\circ} \mathrm{C}$ had only the signals of B-type CAP.

3.5.3. SEM, Static Laser Light Scattering and Specific Surface Area. The surface morphology of the particles was investigated using the SEM method. Micrographs of the initial calcium carbonate are presented in Figure 11. Particles of regular

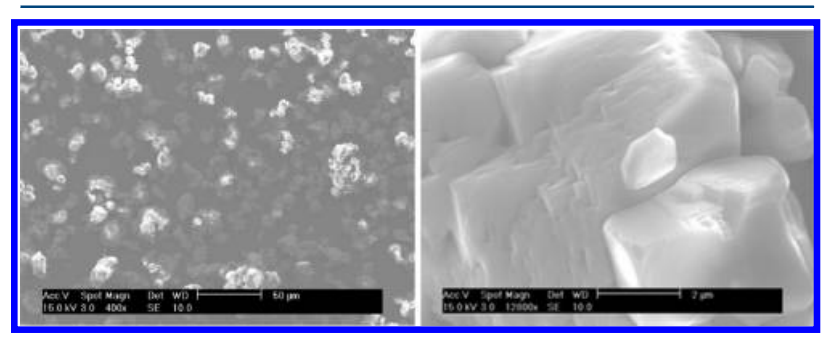

Figure 11. SEM micrographs of the initial calcium carbonate particles.

dimensions with a compact smooth surface were observed, which had the median diameter $\left(d_{50}\right)$ of $13.20 \mu \mathrm{m}$ (Table 2). This seemed to be in agreement with its low specific surface area $\left(S_{\mathrm{BET}},<2 \mathrm{~m}^{2} \mathrm{~g}^{-1}\right.$, Table 2$)$ indicating its nonporous structure.

SEM micrographs at different magnifications of the selected solid products are illustrated in Figure 12. The product synthesized at $25{ }^{\circ} \mathrm{C}$ ( $\left.\mathrm{P} 25-168\right)$ showed a high heterogeneity in particles sizes, varying from some hundreds of nanometers up to $450 \mu \mathrm{m}$, which was confirmed by static laser light scattering. The median diameter $\left(d_{50}\right)$ of this sample was only $0.53 \mu \mathrm{m}$, explained by the presence of numerous particles smaller than $1 \mu \mathrm{m}$ in this sample. The micrograph at the $2 \mu \mathrm{m}$ scale showed that larger particles were formed by the agglomeration of smaller ones. These small particles had a sheet structure, which could be attributed to the presence of OCP and/or brushite in this sample. ${ }^{34,40}$ The frequency of these particles decreased or

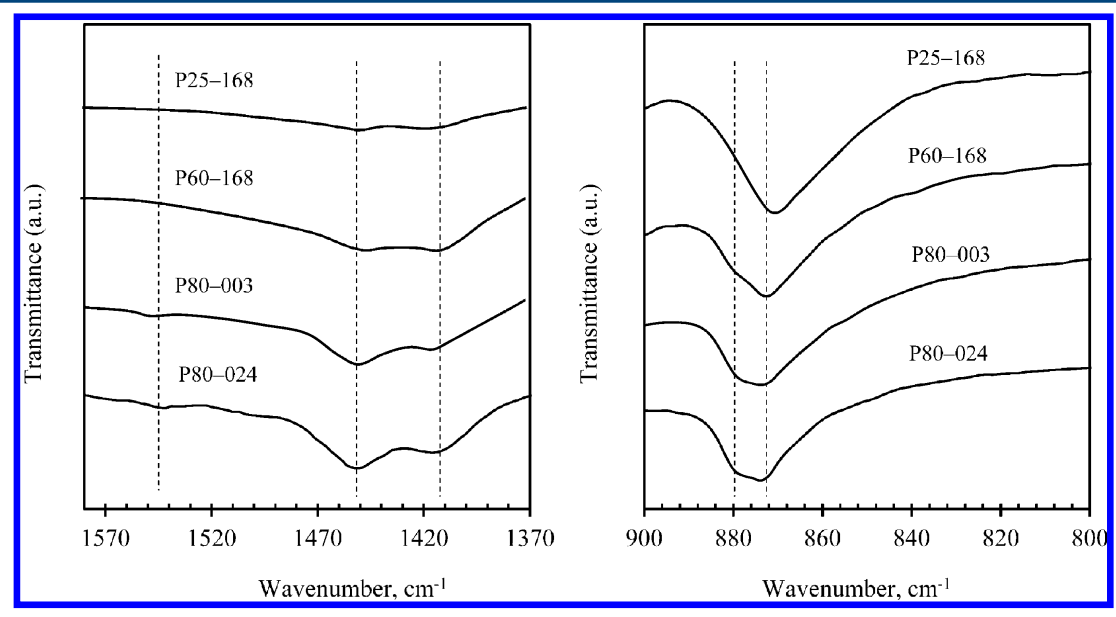

Figure 10. IR spectra of the selected solid products: illustration of A-type CAP (bimodal peak at $1450 \mathrm{~cm}^{-1} / 1415 \mathrm{~cm}^{-1}$ and peak at $873 \mathrm{~cm}^{-1}$ ) and B-type CAP (peaks at 1545 and $880 \mathrm{~cm}^{-1}$ ). 
Table 2. Specific Surface Area $\left(S_{\mathrm{BET}}\right)$ and Median Diameter $\left(d_{50}\right.$, by Static Laser Light Scattering) of the Selected Solid Products

\begin{tabular}{lcc}
\multicolumn{1}{c}{ product } & $S_{\mathrm{BET}}\left(\mathrm{m}^{2} \mathrm{~g}^{-1}\right)$ & $d_{50}(\mu \mathrm{m})$ \\
\hline initial $\mathrm{CaCO}_{3}$ & $<2$ & 13.20 \\
P25-168 & 26 & 0.53 \\
P60-168 & 54 & 0.70 \\
P80-003 & 44 & 0.55 \\
P80-024 & 44 & 0.55 \\
\hline
\end{tabular}

disappeared in the other selected solids, which must be due to their evolution into $\mathrm{Ca}-\mathrm{HA}$ or CAPs phases.

The solid synthesized at $60{ }^{\circ} \mathrm{C}(\mathrm{P} 60-168)$ also had a high heterogeneity in particle sizes. Large particles having plate-like morphology appeared at high frequency, which led to a higher median diameter $\left(d_{50}\right.$ of $\left.0.70 \mu \mathrm{m}\right)$ than that of the solid synthesized at $25{ }^{\circ} \mathrm{C}$. The change was distinct for the products synthesized at $80{ }^{\circ} \mathrm{C}$ (P80-003 and P80-024). Regular spherical particles were formed, and both solid products had the same median diameter of $0.55 \mu \mathrm{m}$.

Specific surface areas of solids can be attributed to both the external surface of particles and the internal surface of pores. Taking into account the median diameters in Table 2, the synthesized solid products must be porous, as observed previously for the solids obtained under similar synthesis conditions. ${ }^{33}$ The increase of the reaction temperature from 25 to $60{ }^{\circ} \mathrm{C}$ favored the decomposition of the initial calcium carbonate and therefore $S_{\mathrm{BET}}$ increased. But the increase of the reaction temperature to $80^{\circ} \mathrm{C}$ led to a slight reduction of $S_{\mathrm{BET}}$. This might be due to the unfavorable effect of the reaction temperature on the specific surface area of $\mathrm{Ca}-\mathrm{HA}$ precipitated in aqueous solution, as observed previously. ${ }^{41}$

3.6. Discussion. As discussed in the Introduction section, the precipitation of a water-soluble calcium salt with a orthophosphate source in an aqueous solution is the most common and classical route for the preparation of $\mathrm{Ca}-\mathrm{HA}$ powder particles. However, it is accompanied by several drawbacks, mostly a high cost of the initial reactant and waste of the counterions. When $\mathrm{Ca}-\mathrm{HA}$-based materials of high purity are required, for example, for pharmaceutical or food applications, an arduous water-rinsing step of the powder suspension to eliminate all counter-ions is also necessary. Calcium hydroxide $\left(\mathrm{Ca}(\mathrm{OH})_{2}\right)$ and orthophosphoric acid seem to be the best alternatives for calcium and orthophosphate sources at the industrial scale. ${ }^{42-44}$ Using these reactants, $\mathrm{Ca}-\mathrm{HA}$ was obtained under moderate reaction conditions of temperature $\left(35-90{ }^{\circ} \mathrm{C}\right) .{ }^{42}$ However, calcium hydroxide is naturally obtained by the calcination of calcium

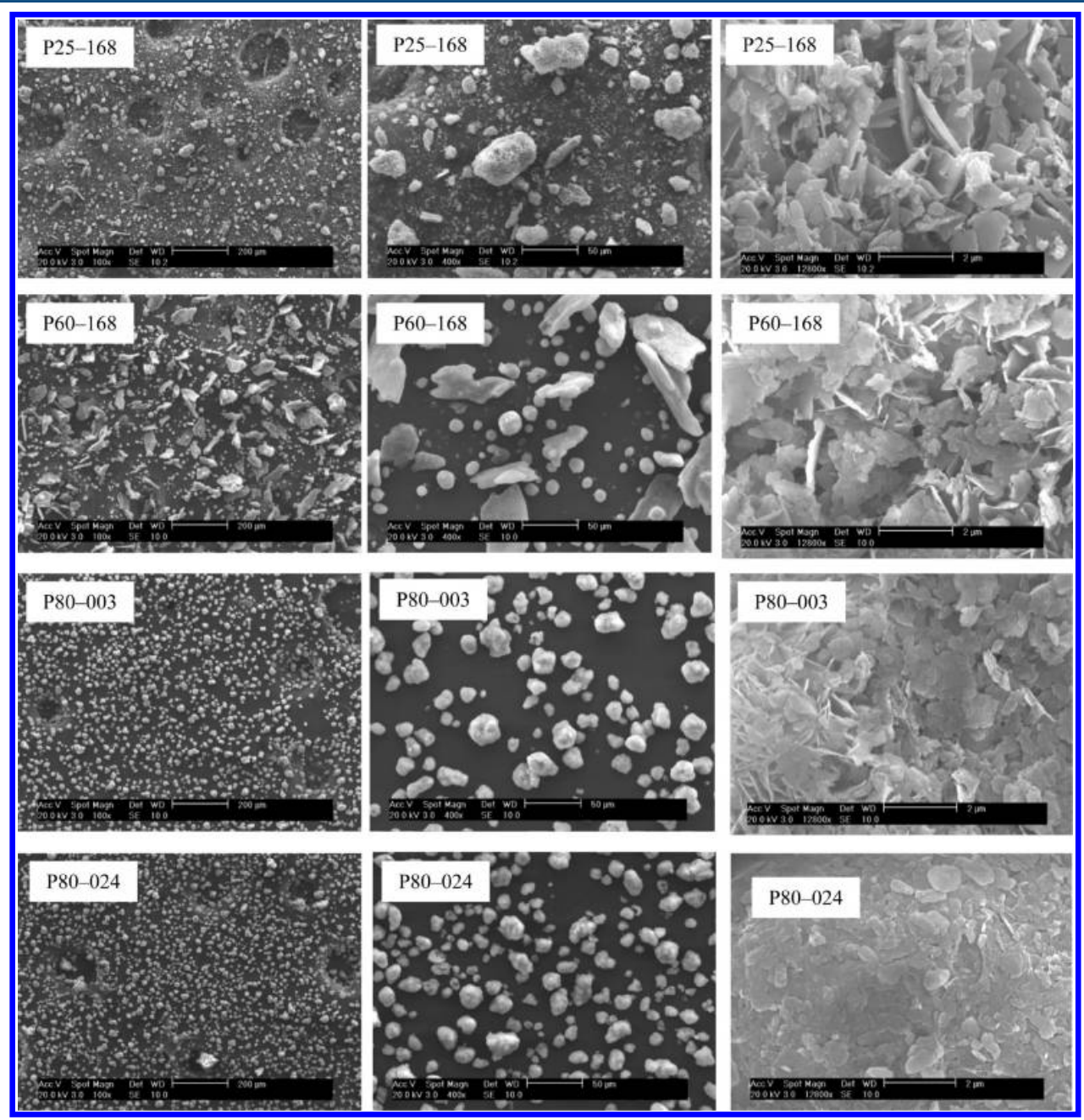

Figure 12. SEM micrographs of the selected solid products. 
carbonate $\left(\mathrm{CaCO}_{3}\right)$, which is an endothermic process, followed by a hydration of resulting calcium oxide (Scheme 1 ).

\section{Scheme 1. Illustration of Industrial and Laboratory Syntheses} of $\mathrm{Ca}-\mathrm{HA}$

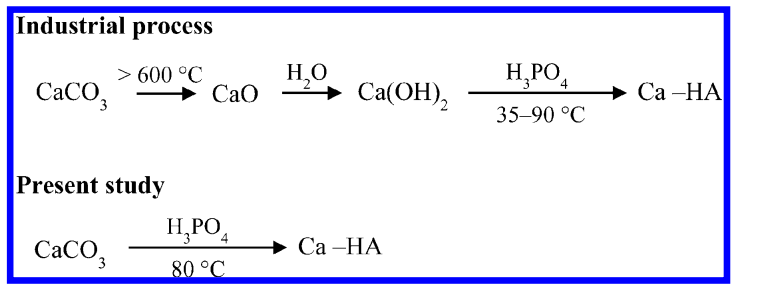

Under similar synthesis conditions of temperature $\left(<90{ }^{\circ} \mathrm{C}\right)$, reaction time $(<24 \mathrm{~h})$ and stirring $(<600 \mathrm{rpm})$, the proposed synthesis process using solely calcium carbonate as-is and orthophosphoric acid has some energetic advantages compared to the competing industrial process using calcium hydroxide and orthophosphoric acid (Scheme 1), thanks to cost savings for calcination and hydration steps. Mixing a suspension of $\mathrm{CaCO}_{3}$ and $\mathrm{H}_{3} \mathrm{PO}_{4}$ at $80^{\circ} \mathrm{C}$ for $24 \mathrm{~h}$ consumes less energy than heating calcium carbonate to at least $600{ }^{\circ} \mathrm{C}$, followed by a hydration step to form $\mathrm{Ca}(\mathrm{OH})_{2}$ and finally a neutralization of $\mathrm{Ca}(\mathrm{OH})_{2}$ with $\mathrm{H}_{3} \mathrm{PO}_{4}$ at the similar synthesis temperature $\left(90{ }^{\circ} \mathrm{C}\right)$. Further study on global costs of the synthesis with respect to reaction conditions such as temperature, reaction time, stirring, etc. may be considered in order to quantify the effectiveness of the proposed synthesis route.

ICP-AES analysis showed only the presence of trace amounts of soluble calcium and orthophosphate ions in the liquid phase, indicating that $\mathrm{Ca}-\mathrm{HA}$ of high purity up to $99 \%$ was obtained without water rinsing step, since all possible counter-ions were practically not present. For the P-80-024 sample, the overall yield of the synthesis in the solid product was $98 \%$, taking into account the complete conversion of calcite and orthophosphoric acid used, the high selectivity in the formation of apatitic compounds ( $\mathrm{Ca}-\mathrm{HA}$ and CAP), and the weight of the solid product recovered after filtration and drying at $105^{\circ} \mathrm{C}$.

\section{CONCLUSIONS}

A one-step synthesis of $\mathrm{Ca}-\mathrm{HA}$ from calcium carbonate and orthophosphoric acid was investigated under moderate reaction conditions. The stirring rate and the weight ratio of water to calcium carbonate $(\mathrm{L} / \mathrm{S})$ had slight effect on the advancement of the reaction. On the other hand, the reaction temperature and the reaction time were found to be crucial for the decomposition of calcium carbonate, which was the key step for the formation of stoichiometric $\mathrm{Ca}-\mathrm{HA}$. The essential reaction conditions for a total conversion of the initial reactants $\left(\mathrm{CaCO}_{3}\right.$ and $\left.\mathrm{H}_{3} \mathrm{PO}_{4}\right)$ into desired products $(\mathrm{Ca}-\mathrm{HA})$ were determinate. Calcium carbonate decomposed nearly completely at $80{ }^{\circ} \mathrm{C}$ after $24 \mathrm{~h}$ of reaction and stoichiometric $\mathrm{Ca}-\mathrm{HA}$ was obtained together with small amounts of carbonate-containing apatites (CAP). Carbon dioxide was the only by-product of the reaction. No water rinsing step was required thanks to the absence of other unneeded ions or molecules, and thanks to the complete transformation of the initial reactants into apatitic solids. Future work may further investigate the optimization of the one-step synthesis of $\mathrm{Ca}-\mathrm{HA}$. Kinetic modeling of calcite decomposition and $\mathrm{Ca}-\mathrm{HA}$ crystal growth may be also considered. The investigation of the resulting $\mathrm{Ca}-\mathrm{HA}$ as acid-base catalysts and supports for the dispersion of metal nanoparticles is planned, as is the use of $\mathrm{Ca}-\mathrm{HA}$ gel for water and gas purification processes.

\section{AUTHOR INFORMATION}

\section{Corresponding Author}

*Tel.: +33 563493258. Fax: +33 563493043. E-mail: doan. phamminh@mines-albi.fr.

\section{Notes}

The authors declare no competing financial interest.

\section{ACKNOWLEDGMENTS}

We thank our colleagues, Nathalie Lyczko, Christine Rolland, Philippe Accart, and Denis Marty for their technical help.

\section{REFERENCES}

(1) Zamoume, O.; Thibault, S.; Regnié, G.; Mecherri, M. O.; Fiallo, M.; Sharrock, P. Macroporous calcium phosphate ceramic implants for sustained drug delivery. Mater. Sci. Eng., C 2011, 31, 1352-1356.

(2) Nathanael, A. J.; Hong, S. I.; Mangalaraj, D.; Chen, P. C. Large scale synthesis of hydroxyapatite nanospheres by high gravity method. Chem. Eng. J. 2011, 173, 846-854.

(3) Rossi, A. L.; Barreto, I. C.; Maciel, W. Q.; Rosa, F. P.; Rocha-Leão, M. H.; Werckmann, J.; Rossi, A. M.; Borojevic, R.; Farina, M. Ultrastructure of regenerated bone mineral surrounding hydroxyapatite-alginate composite and sintered hydroxyapatite. Bone 2012, 50, 301-310.

(4) Solhy, A.; Tahir, R.; Sebti, S.; Skouta, R.; Bousmina, M.; Zahouily, M.; Larzek, M. Efficient synthesis of chalcone derivatives catalyzed by reusable hydroxyapatite. Appl. Catal. A: Gen. 2010, 374, 189-193.

(5) Mondelli, C.; Ferri, D.; Baiker, A. Ruthenium at work in Ruhydroxyapatite during the aerobic oxidation of benzyl alcohol: An in situ ATR-IR spectroscopy study. J. Catal. 2008, 258, 170-176.

(6) Park, J. H.; Lee, D. W.; Im, S. W.; Lee, Y. H.; Suh, D. J.; Jun, K. W.; Lee, K. Y. Oxidative coupling of methane using nonstoichiometric lead hydroxyapatite catalyst mixtures. Fuel 2012, 94, 433-439.

(7) Jemal, J.; Tounsi, H.; Chaari, K.; Petitto, C.; Delahay, G.; Djemel, S.; Ghorbel, A. NO reduction with $\mathrm{NH}_{3}$ under oxidizing atmosphere on copper loaded hydroxyapatite. Appl. Catal. B: Environ. 2012, 113-114, 255-260.

(8) Mene, R. U.; Mahabole, M. P.; Khairnar, R. S. Surface modified hydroxyapatite thick films for $\mathrm{CO}_{2}$ gas sensing application: Effect of swift heavy ion irradiation. Radiat. Phys. Chem. 2011, 80, 682-687.

(9) Mene, R. U.; Mahabole, M. P.; Sharma, R.; Khairnar, R. S. Enhancement in CO gas sensing properties of hydroxyapatite thick films: Effect of swift heavy ion irradiation. Vacuum 2011, 86, 66-71.

(10) Baillez, S.; Nzihou, A.; Bernache-Assolant, D.; Champion, E.; Sharrock, P. Removal of aqueous lead ions by hydroxyapatites: Equilibria and kinetic processes. J. Hazard. Mater. 2007, A139, 443446.

(11) Bhatnagar, A.; Kumar, E.; Sillanpää, M. Fluoride removal from water by adsorption-A review. Chem. Eng. J. 2011, 171, 811-840.

(12) Nakamura, S.; Isobe, T.; Senna, M. Hydroxyapatite nano sol prepared via a mechanochemical route. J. Nanopart. Res. 2001, 3, 57-61.

(13) Silva, C. C.; Pinheiro, A. G.; Miranda, M. A. R.; Góes, J. C.; Sombra, A. S. B. Structural properties of hydroxyapatite obtained by mechanosynthesis. Solid State Sci. 2003, 5, 553-558.

(14) Itatani, K.; Iwafune, K.; Howell, F. S.; Aizawa, M. Preparation of various calcium-phosphate powders by ultrasonic spray freeze-drying technique. Mater. Res. Bull. 2000, 35, 575-585.

(15) Luo, P.; Nieh, T. G. Preparing hydroxyapatite powders with controlled morphology. Biomaterials 1996, 17, 1959-1964.

(16) Anee, T. K.; Ashok, M.; Palanichamy, M.; Kalkura, S. N. A novel technique to synthesize hydroxyapatite at low temperature. Mater. Chem. Phys. 2003, 80, 725-730.

(17) Bezzi, G.; Celotti, G.; Landi, E.; La Torretta, T. M. G.; Sopyan, I.; Tampieri, A. A novel sol-gel technique for hydroxyapatite preparation. Mater. Chem. Phys. 2003, 78, 816-824. 
(18) Salimi, M. N.; Bridson, R. H.; Grover, L. M.; Leeke, G. A. Effect of processing conditions on the formation of hydroxyapatite nanoparticles. Powder Technol. 2012, 218, 109-118.

(19) Jarcho, M.; Bolen, C. H. Hydroxylapatite synthesis and characterization in dense polycrystalline form. J. Mater. Sci. 1976, 11, 2027-2035.

(20) Rodriguez-Lorenzo, L. M.; Vallet-Regi, M.; Ferreira, J. M. F. Fabrication of hydroxyapatite bodies by uniaxial pressing from a precipitated powder. Biomaterials 2001, 22, 583-588.

(21) Bailliez, S.; Nzihou, A. The kinetics of surface area reduction during isothermal sintering of hydroxyapatite adsorbent. Chem. Eng. J. 2004, 98, 141-152.

(22) Swain, S. K.; Dorozhkin, S. V.; Sarkar, D. Synthesis and dispersion of hydroxyapatite nanopowders. Mater. Sci. Eng., C 2012, 32, 12371240.

(23) Okada, M.; Fujii, S.; Nishimura, T.; Nakamura, Y.; Takeda, S.; Furuzono, T. Solvent-free formation of hydroxyapatite coated biodegradable particles via nanoparticle-stabilized emulsion route. Appl. Surf. Sci. 2012, DOI: 10.1016/j.apsusc.2012.01.016.

(24) Saha, S. K.; Banerjee, A.; Banerjee, S.; Bose, S. Synthesis of nanocrystalline hydroxyapatite using surfactant template systems: Role of templates in controlling morphology. Mater. Sci. Eng., C 2009, 29, 2294-2301.

(25) Ipekoglu, M.; Altintas, S. Silver substituted nanosized calcium deficient hydroxyapatite. Mater. Technol.: Adv. Perform. Mater. 2010, 25, 295-301.

(26) Vasile, E.; Popescu, L. M.; Piticescu, R. M.; Burlacu, A.; Buruiana, T. Physico-chemical and biocompatible properties of hydroxyapatite based composites prepared by an innovative synthesis route. Mater. Lett. 2012, 79, 85-88.

(27) Murakami, S.; Kato, K.; Enari, Y.; Kamitakahara, M.; Watanabe, N.; Ioku, K. Ceram. Int. 2012, 38, 1649-1654.

(28) Son, K. D.; Yang, D. J.; Kim, M. S.; Kang, I. K.; Kim, S. Y.; Kim, Y. $\mathrm{J}$. Effect of alginate as polymer matrix on the characteristics of hydroxyapatite nanoparticles. Mater. Chem. Phys. 2012, 132, 10411047.

(29) Gopi, D.; Indira, J.; Kavitha, L.; Sekar, M.; Mudali, U. K. Synthesis of hydroxyapatite nanoparticles by a novel ultrasonic assisted with mixed hollow sphere template method. Spectrochim. Acta 2012, A93, 131-134.

(30) Rouhani, P.; Taghavinia, N.; Rouhani, S. Rapid growth of hydroxyapatite nanoparticles using ultrasonic irradiation. Ultrason. Sonochem. 2010, 17, 853-856.

(31) Shepard, S. R.; Brickman-Stone, C.; Schrimsher, J. L.; Koch, G. Discoloration of ceramic hydroxyapatite used for protein chromatography. J. Chromatogr. A 2000, 891, 93-98.

(32) McCue, J. T.; Cecchini, D.; Hawkins, K.; Dolinski, E. Use of an alternative scale-down approach to predict and extend hydroxyapatite column lifetimes. J. Chromatogr. A 2007, 1165, 78-85.

(33) Pham Minh, D.; Lyczko, N.; Sebei, H.; Nzihou, A.; Sharrock, P. Synthesis of calcium hydroxyapatite from calcium carbonate and different orthophosphate sources: A comparative study. Mater. Sci. Eng., B 2012, 177, 1080-1089.

(34) Horváthová, R.; Müller, L.; Helebrant, A.; Greil, P.; Müller, F. A. In vitro transformation of $\mathrm{OCP}$ into carbonated $\mathrm{HA}$ under physiological conditions. Mater. Sci. Eng., C 2008, 28, 1414-1419.

(35) Yao, F.; LeGeros, R. Z. Carbonate and fluoride incorporation in synthetic apatites: Comparative effect on physico-chemical properties and in vitro bioactivity in fetal bovine serum. Mater. Sci. Eng., C 2010, 30, $423-430$.

(36) Yoğurtcuoğlu, E.; Uçurum, M. Surface modification of calcite by wet-stirred ball milling and its properties. Powder Technol. 2011, 214, $47-53$.

(37) Pham Minh, D.; Sebei, H.; Nzihou, A.; Sharrock, P. Apatitic calcium phosphates: Synthesis, characterization and reactivity in the removal of lead(II) from aqueous solution. Chem. Eng. J. 2012, 198199, 180-190.

(38) Wilson, R. M.; Elliott, J. C.; Dowker, S. E. P.; Smith, R. I. Rietveld structure refinement of precipitated carbonate apatite using neutron diffraction data. Biomaterials 2004, 25, 2205-2213.
(39) Antonakos, A.; Liarokapis, E.; Leventouri, T. Micro-Raman and FTIR studies of synthetic and natural apatites. Biomaterials 2007, 28, 3043-3054.

(40) Cama, G.; Barberis, F.; Capurro, M.; Di Silvio, L.; Deb, S. Tailoring brushite for in situ setting bone cements. Mater. Chem. Phys. 2011, 130, 1139-1145.

(41) Kothapalli, C.; Wei, M.; Vasiliev, A.; Shaw, M. T. Influence of temperature and concentration on the sintering behavior and mechanical properties of hydroxyapatite. Acta Mater. 2004, 52, 56555663.

(42) Conn J. F.; Jessen L. A. Process for producing hydroxyapatite, U.S. Patent 4,324,772, November, 1980.

(43) Innovadex. http://www.innovadex.com/Food/Detail/5454/ 203586/PRAYPHOS-TCP-308-FG (accessed August 2012).

(44) Innophos. http://www.innophos.com/en/products-andmarkets/browse-product-categories/phosphate-salt/tricalciumphosphates/tricalcium-phosphate-nf-fcc (accessed August 2012). 